\title{
IMPACT OF INNOVATION CLIMATE ON INDIVIDUAL AND ORGANISATIONAL LEVEL FACTORS IN ASIA AND EUROPE
}

\author{
Ülle Übius ${ }^{1}$, Ruth Alas ${ }^{2}$, Tiit Elenurm ${ }^{3}$ \\ Estonian Business School, Lauteri 3, 10114 Tallinn, Estonia \\ E-mails: ${ }^{1} y l l e . y b i u s @ e b s . e e(c o r r e s p o n d i n g a u t h o r) ;{ }^{2}$ ruth.alas@ebs.ee; ${ }^{3}$ tiit.elenurm@ebs.ee \\ Received 30 March 2011; accepted 14 November 2011
}

\begin{abstract}
Organisation climate plays an important role for the innovation of an organisation. The purpose of this paper is to investigate connections between the innovation climate and individual and organisational level factors. Surveys were conducted among Japanese, Chinese, Estonian, Czech and Slovakian enterprises. Linear regression analysis was conducted. The results of an empirical study show that the innovation climate predicts differently some individual and organisational level factors in studied countries. Two innovation climate facets - commitment and freedom predict individual level factors- attitude toward the firm in all 5 countries. In two studied Asian countries, Japan and China, commitment predicts meaning of work and job satisfaction whereas in all three new European Union member states some links between facets of the innovation climate and individual meaning of work and job satisfaction were missing. Although individual job satisfaction and meaning of work in is still shaped by to some extent different mechanisms in studied countries, implications of the innovative climate for organisation are more similar, at least in industries that are influenced by rapid technological development and globalization.
\end{abstract}

Keywords: innovation, satisfaction, meaningfulness, management, Asia, Europe.

Reference to this paper should be made as follows: Übius, Ü.; Alas, R.; Elenurm, T. 2013. Impact of innovation climate on individual and organisational level factors in Asia and Europe, Journal of Business Economics and Management 14(1): 1-21.

JEL Classification: O31.

\section{Introduction}

The resource-based view of the firm (Barney 1991; Wright et al. 2005) has been instrumental in explaining differences in innovation activities among firms. Dynamic capabilities mean the ability to continuously reconfigure resources (Teece et al. 1997). Employees' attitudes have been studied in countries with different historical and institutional backgrounds (Alas 2003; Alas, Edwards 2005, 2011). Different cultural environments have been compared concerning organizations individual level factors (Alas, Tuulik 2007). Organisation climate plays an important role for mobilizing innovative resources and capabilities of organisations. This study investigates how the innovation climate predicts individual and organisational level factors among Japanese, Chinese, Estonian, Slovakian and Czech electric-electronic machine, retail store, information-software pro- 
duction and machine-building enterprises. Previous studies have shown that aggregate job satisfaction is a significant predictor of subsequent organisational innovation (Shipton et al. 2004), units are more innovative when the firm emphasizes personalized, intrinsic rewards (such as meaningful work opportunities) (Judge et al. 1997). According to Garcia-Gofii et al. (2007) managers' behaviour depends more on individual and organisational innovative profiles. Innovations that accurately reflect market realities are more likely to lead to sustainable competitive advantage (Deming 1986; Porter 1985). Brown and Frame (2004) unfold the subjectivity of innovation management. The main aim of the study is to find connections between the innovation climate, individual and organisational level factors.

Authors decided to study countries with very different cultural, historical and institutional background. Previous studies has shown that innovation is more influenced by society and institutional background. Therefore authors carried out this research in organizations that are operating in capitalistic economy (Japan), socialist planned economy (China) and transitional economy (Estonia, Czech Republic, Slovakia) which gives possibility to compare countries from institutional perspective. Furthermore the countries with transitional economy are dividend by their historical background. Estonia represents the republics of the former Soviet Union and Czech Republic and Slovakia represent the former independent socialist countries.

A standardised job satisfaction, meaning of work, attitude toward the firm, powerfulness of firm in competition against rivals and behaviour of management questionnaires were developed by the Denki Ringo research group (Ishikawa et al. 2006). The questionnaires were administered among Japanese, Chinese, Estonian, Slovakian and Czech electricelectronic machine, retail store, information-software production and machine-building enterprises. The linear regression analysis was used in order to find statistically relevant connections between the innovation climate, individual and organisational level factors. The main research question is: does the innovation climate predict individual and organisational level factors?

The main findings of the current study are following. The innovation climate facets predict both organisational level factors - powerfulness of firm in competition against rivals and behaviour of management. The innovation climate predicts almost all individual level factors - job satisfaction, meaning of work and attitude toward the firm in this study, except the innovation climate facet - positive relationship does not predict job satisfaction and the innovation climate facet - freedom does not predict meaning of work. In different countries innovation climate facets predict individual and organisational level factors differently.

\section{Theoretical framework}

\subsection{The innovation climate}

According to Amabile et al. (1996) all humans with normal capacities are able to produce moderately creative work in some domain and social environment has the influence on the level and the frequency of creative behaviour. Mathisen and Einarsen (2004) state that the most common to the creativity is the fact that group members are free to 
define most of their work, they originate and develop the ideas, processes and solutions with which they work. Buckler and Zien (1996) state that innovation is the purpose of the whole organisation. In an organisation that has strong innovative climate, new ideas come forward into an atmosphere of enthusiastic support and a desire to contribute to them, even though everyone knows that the majority of these ideas will not make it to market. Innovative companies are on the lookout to continually refresh this climate, because it can be undermined. Thinking "outside the box" is certainly a major characteristic of an innovative environment (Buckler, Zien 1996). Ekvall and Ryhammar (1999) have found that there are important connections between business results of organisations and innovative climate. The innovation climate that is the degree to which an organisation offers its employees support and encouragement to take initiative and explore innovative approaches that influences the degree of actual innovation in that organisation (Martins, Terblanche 2003; Mumford, Gustafson 1988).

Smith (2002), and Unsworth and Parke (2003) have found that individual innovation helps to attain organisational success. Employee innovative behaviour depends mostly on their interaction with others in the workplace (Anderson et al. 2004; Zhou, Shalley 2003). According to Damanpour and Schneider (2006), the climate for innovation is a direct result of the top managers' personal and positional characteristics.

Ekvall (1999) states that innovative organisations have the capacity to adapt to constantly changing environments in order to survive and these adaptive organisations require climate that stimulate creative behaviour.

According to Schneider and Reichers (1983) the separation of climate from culture research may be an artifact of time that will diminish in the future (Ashforth 1985). Climate and culture have overlapped in their evolution in the field of organizational psychology only for about ten years. In an Annual Review of Psychology article, Schneider (1985) reviewed culture and climate literatures and suggested ways in which they complement each other. These recent articles may indicate a trend in the development of both concepts toward a marriage of methods and terminology. The next ten years in the evolution of both concepts would yield an amalgamated climate/culture concept that exhibits many of the conceptual, methodological, and practical characteristics that are presently unique to one concept or the other according to Schneider and Reichers (1983).

\subsection{Theoretical basis for individual level factors in the Denki Ringo questionnaire}

\subsubsection{Job satisfaction}

Brayfield and Rothe (1951) stated that job satisfaction is individual's attitude towards their work.

According to Sockel et al. (2004) employees' perception of innovation has a direct impact on their level of job satisfaction.

Locke's (1976) states in his range of affect theory that satisfaction is determined by a discrepancy between what one wants in a job and what one has in a job. According to 
Judge's et al. (2001) Core Self-evaluations Model there are four Core Self-evaluations that determine one's disposition towards job satisfaction: self-esteem, general self-efficacy, locus of control and neuroticism.

Herzberg (1968) explains in his two-factor theory satisfaction in the workplace. This theory states that different factors - motivation and hygiene factors drive satisfaction and dissatisfaction. Motivating factors are facets of the job that bring job satisfaction and make people want to perform, for example, recognition and achievement in work. Hygiene factors include facets of the working environment such as company policies, a pay and other working conditions.

Hackman and Oldham's (1976) Job Characteristics Model is used to study how job characteristics impact on job satisfaction. Hackman and Oldham (1975) suggest that jobs differ concerning five core dimensions: skill variety, task identity, task significance, autonomy and task feedback. They suggest that three critical psychological states occur in employees: experienced meaningfulness of work, experienced responsibility for work outcomes and the knowledge of the results of work activities if jobs are designed in a way that increases the presence of the core characteristics. Work motivation and job satisfaction will be high if these critical psychological states are experienced. Alas (2003) found that intrinsic factors of job satisfaction in the traditional capitalist countries have a greater correlation with feelings toward the company and general job satisfaction than extrinsic factors. Countries with a socialist past have to deal with the satisfaction of needs at a lower level than traditional capitalist countries and this consequently influences attitudes and expectations toward society, trade unions, organisations and work.

Silverthome (2004) found that organisational culture plays an important role in the level of job satisfaction and commitment in an organisation. Lund (2003) examined the influence of types of organisational culture on job satisfaction according to Cameron and Freeman's (1991) model of organisational cultures comprising clan, adhocracy, hierarchy and market. The results indicate that job satisfaction varied across corporate cultural typology. Job satisfaction was positively related to clan and adhocracy culture types and negatively related to market and hierarchy culture types.

\subsubsection{Meaning of work}

Dewey (1939) states that goodness is the outcome of "valuation", a continuous balancing of personal or cultural value, which he called "ends in view." According to Seel (2005), organisational culture is the emergent result of continuing negotiations about values, meanings and proprieties between the members of that organisation and with its environment. According to Stevens (1999), effective strategy implementation depends on the extent to which resultant changes conform to existing knowledge structures used by members of the organisation to make sense of and give meaning to their work. Such cognitive paradigms form the culture construct of the organisation.

\subsubsection{Attitudes toward the firm}

Organisational commitment is a work-related attitude. It means the employee's psychological attachment to the organisation. Meyer and Allen's (1991) three-component model of commitment characterizes an employee's commitment to the organisation: 
affective commitment is defined as the employee's positive emotional attachment to the organisation; continuance commitment is where the individual commits to the organisation because he/she perceives high costs of losing organisational membership, including economic costs and social costs that would be incurred; normative commitment is where the individual commits to and remains with an organisation because of feelings of obligation. Many studies have indicated that attitudes are impacted by institutional background (Alas 2008; Tafel, Alas 2007).

\subsection{Theoretical basis of organisational level factors in the Denki Ringo questionnaire}

\subsubsection{The behaviour of the management}

Behavioural management theory describes the human dimension of work. Behavioural theorists state that a better understanding of human behaviour at work through such aspects as motivation, expectations and group dynamics, improves productivity. The theorists of this school view employees as individuals, resources and assets to be developed and worked with.

McGregor's (1957) idea was that managers following "Y theory" and supporting selffulfilment of employees can create self-fulfilling prophecies - through their behaviour, these managers create situations, where subordinates act in ways that confirm the manager's original expectations. Schein (2004) states that organisational cultures are created by leaders and one of the most decisive functions of leadership may well be the creation, management and - if and when necessary - the destruction of culture. Kanne-Urrabazo (2006) states that many managers do not deny the importance of organisational culture in employee satisfaction, few fail to realize the direct impact they have in shaping it. It is crucial that managers are aware of their roles and responsibilities in upholding positive workplace environments that can increase employee satisfaction.

\subsubsection{The powerfulness of the firm in competition with rivals}

Porter (2008) states that competition and competitive strategy consist of three categories: core concepts, location as a competitive advantage and competitive solutions to societal problems. Cameron and Quinn (1999) state that the major distinguishing feature in successful companies is their organisational culture. It is their most important competitive advantage and the most powerful factor they all highlight as a key ingredient in their success. Barney (1986) states that three attributes that organisation culture must have to generate sustained competitive advantage are isolated. Previous findings suggest that the cultures of some organisations have these attributes; thus, these cultures are a source of such advantage.

\subsection{Earlier research on connections between the innovation climate and individual level factors}

\subsubsection{The innovation climate and job satisfaction}

According to Shipton et al. (2004) aggregate job satisfaction was a significant predictor of subsequent organisational innovation, even after controlling for prior organisational innovation and profitability. The data indicated that the relationship between job satis- 
faction and innovation in production technology/processes (but not product innovation) is mediated by organisational job variety, harmonization and contingent pay. Research also shows that job satisfaction is significantly associated with measures of discretionary behaviours classed as Organisational citizenship: helping, loyalty, compliance and innovation (Podsakoff et al. 2000).

\subsubsection{The innovation climate and meaningful work}

According to Judge et al. (1997), units are more innovative when the firm emphasizes personalized, intrinsic rewards (those that were related to the work and elicited feelings of accomplishment, such as peer and supervisor recognition, meaningful work opportunities) as opposed to extrinsic (bonuses, stock options).

\subsubsection{The innovation climate and attitude toward the firm}

According to Jones (1995), consultants and academics are urged to highlight the need to tackle core attitudes at the head of organisations as the key prerequisite of radical culture change, high learning and innovation, and long-term competitiveness. According to Garcia-Gofii (2007), perception of innovation is different for managers and front-line employees in public health institutions. Front-line employees' attitude depends usually on the overall performance of the institution. Managers' behaviour depends more on individual and organisational innovative profiles and they feel more involved and motivated.

\subsection{Connections between the innovation climate and organisational level factors}

\subsubsection{The innovation climate and powerfulness of firm in competition against rivals}

The link between innovation activities and competitive advantage depends on four factors. First, innovations that are hard to imitate are more likely to lead to sustainable competitive advantage (Clark 1987; Porter 1985). Secondly, innovations that accurately reflect market realities are more likely to lead to sustainable competitive advantage (Deming 1986; Porter 1985). Thirdly, innovations that enable a firm to exploit the timing characteristics of the relevant industry are more likely to lead to sustainable competitive advantage (Betz 1987; Kanter 1983). Fourthly, innovations that rely on capabilities and technologies that are readily accessible to the firm are more likely to lead to sustainable competitive advantage (Ansoff 1988; Miller 1990).

\subsubsection{The innovation climate and behaviour of management}

According to Ortt and Smits (2006) four general consequences of the trends in innovation management are: 1) the end of the linear model; 2) the rise of the systems approach; 3) the uncertainty and need for learning; 4) entrepreneurship. Brown and Frame (2004) unfold the subjectivity of innovation management, and the essential role that sub-cultures and innovation process outcome criteria play in the innovation journey. According to Birkinshaw and Mol (2006), management innovation tends to be diffuse and gradual. According to Fariborz (1991), innovations are the vehicle to introduce change into outputs, structure and processes and factors at different levels - individual, 
organisational and environmental as the environment changes and demands organisations to change and adapt to new conditions. Mumford and Gustavson (1988) stated that organisational innovation depends on the climate for innovation.

\section{The propositions for empirical analysis}

Based on the overview of the individual level and organisational level factors identified in the literature overview and reflected in the Denki Ringo questionnaire, the authors assume that the different facets of the innovation climate - commitment, positive relationship, shared view, freedom, idea-support and risk-taking predict individual and organisational level factors - job satisfaction, meaning of work, attitudes toward the firm, powerfulness of the firm in competition with rivals, behaviour of the management. According to Ekvall (1990), innovative organisations score high in following dimensions - challenge/ motivation, freedom, idea-support, trust, dynamism, humour, debate, risk-taking and idea-time. According to Ekvall (1990) and Nyström (1990), a climate that supports innovation can enable its members to generate and implement creative ideas more effectively. Correspondingly the first two propositions are about the connections between the innovation climate, individual and organisational level factors. First two propositions are:

P1. The innovation climate facets predict individual level factors - job satisfaction, meaning of work and attitude toward the firm.

P2. The innovation climate facets predict organisational level factors - powerfulness of firm in competition against rivals and behaviour of management.

Earlier research evidence does not give clear indication which of individual and organisational level factors are influenced more strongly and on which of these factors the innovative climate has weaker impact. Empirical research results will be used in order to assess possible differences between impact of the innovative climate on these factors.

Social, cultural, historical, economic and political environment where organisations operate influence these connections. The third proposition is about the differences between Estonia, Japan, China, Czech Republic and Slovakia concerning the connections between the innovation climate, individual and organisational level factors in the institutional and cultural environment of China as a large Asian emerging economy and three new member states of the Europan Union that have different cultural background.

P3. The innovation climate facets predict individual and organisational level factors differently in different countries.

Organisational culture analysis is very important because shared beliefs and norms affect employee perceptions, behaviours and emotional responses to the workplace. For example, culture has been found to influence organisational climate and provider attitudes including work attitudes (Aarons, Sawitzky 2006; Carmazzi, Aarons 2003; Glisson, Hemmelgam 1998; Glisson, Lames 2002), as well as employee behaviours that contribute to the success or failure of an organisation (Ashkanasy, Wilderom, Peterson 2000). In order to focus on cross-cultural differences between five countries, the industry composition of samples for the empirical study was aligned in Estonian, Chinese, Japanese, Slovakian and Czech Republic. 


\section{The empirical study}

\subsection{The sample}

The authors organised and conducted the survey among 8 Estonian enterprises and in 4 fields - electrical-electronic machine, retail, information-software production and machine-building enterprises. Authors used a questionnaire and conducted interviews among Estonian enterprises by themselves. The authors made contact with the member of the board in Estonian organisations and obtained permission to conduct this study. After that the questionnaire was sent by e-mail to the respondents in each enterprise. The answers were also sent back by e-mail.

The research was done among Japanese enterprises with 1570 respondents, among Chinese enterprises with 1150 respondents, among Estonian enterprises with 623 respondents, among Slovakian enterprises with 605 respondents and among Czech enterprises with 1110 respondents. The companies were selected among enterprise that have largest market share in these sectors that were chosen for the survey. The total number of respondents was 5058. The survey was conducted among electrical-electronic machine, retail, information-software production and machine-building enterprises.

Authors decided to study countries with different social, economic and institutional background. Previous studies has shown that innovation is more influenced by society and institutional background. Therefore, author has carried out this research in organizations that are operating in capitalistic economy (Japan), socialist planned economy (China) and transitional economy (Estonia, Czech Republic, Slovakia) which gives possibility to compare countries operating in different environments. Furthermore, the countries from transitional economies are divided by their historical background. Estonia represents the republics of the former Soviet Union and Czech Republic and Slovakia represent the former independent socialist countries. Participation in Denki Ringo research group enabled the autor to compare countries from capitalistic, socialist planned and transitional economies.

\subsection{The procedure}

The author has conducted empirical research among Estonian, Chinese, Japanese, Czech and Slovakian enterprises. In the research process the author worked out following instrument: a scale for evaluating innovation climate. The author's used following questionnaires were worked out by the Denki Ringo research group: questionnaires for assessing job satisfaction, meaning of work, attitudes toward the firm, powerfulness of firm in competition against rivals and behaviour of management.

The empirical research task was to identify connections between the innovation climate, individual and organisational level factors on the basis of propositions that were developed in the theoretical framework. Authors used a questionnaire and conducted interviews among Estonian enterprises by themselves. The authors made contact with the member of the board in Estonian organisations and obtained permission to conduct this study. After that the questionnaire was sent by e-mail to the respondents in each enterprise. The answers were also sent back by e-mail. 
The authors obtained the file with Japanese, Chinese, Slovakian and Czech respondents' answers from the Japanese co-partner of the Denki Ringo (Ishikawa et al. 2006) research group in order to conduct comparative analysis.

A linear regression analysis was used in order to find statistically relevant connections based on the main research question: how does the innovation climate predict individual and organisational level factors?

\subsection{The measurements}

The authors developed an innovation climate scale based on the Innovation Climate Questionnaire introduced by Ekvall et al. (1983). Items to measure the innovation climate were selected. The internal consistency, or Cronbach Alpha coefficient was 0.70. The final version of the questionnaire for measuring innovation climate consisted of 14 items. Six innovation climate facets - commitment, positive realationship, shared view, freedom, idea-support and risk-taking were measured. Ekvall et al.'s (1983) innovation climate questionnaire (ICQ) incorporates thirteen scales: commitment, freedom, idea-support, positive relationships, dynamism, playfulness, idea-proliferation, stress, risk-taking, idea-time, shared view, pay recognition and work recognition.

The authors used questionnaires worked out by the Denki Ringo research group in Japan for measuring the following individual level factors - job satisfaction, meaning of work and attitude toward the firm; and the following organisational level factors - the behaviour of the management and the powerfulness of the firm in competition with rivals. A standardised questionnaire with 44 items was used in every country. The questions were divided between topics as follows: job satisfaction (16 questions), meaning of work (6 questions), attitudes toward the firm (6 questions), the powerfulness of the firm in competition with rivals (10 questions), the behaviour of the management (6 questions). All of these questions were evaluated on a five-point scale.

\section{Results}

In the analysis the innovation climate factors were analyzed as independent variables and individual and organisational level factors reflected in the Denki Ringo questionnaire as dependent variables. We calculated a standardised regression coefficient Beta, which enabled us to predict how strongly the innovation climate facets forecast individual and organisational level factors (Table 1,2,3,4,5). Analysis was applied separately for five different countries and every dependent and independent variables.

According to the linear regression analysis results in Table 1, in Chinese enterprises individual level factors - job satisfaction is predicted by innovation climate factors commitment, shared view, freedom and risk-taking $\left(\mathrm{R}^{2}=.199, \mathrm{~F}(6.1143)=47.454\right.$, $\mathrm{p}<.000)$, meaning of work is predicted by commitment and idea-support $\left(\mathrm{R}^{2}=.161\right.$, $\mathrm{F}(6.1143)=36.739, \mathrm{p}<.000)$ and attitude toward the work is predicted by commitment, positive relationship and freedom $\left(\mathrm{R}^{2}=.316, \mathrm{~F}(6.1143)=89.729, \mathrm{p}<.000\right)$. Organisational level factors - behaviour of management is predicted by commitment, freedom and idea-support $\left(\mathrm{R}^{2}=.473, \mathrm{~F}(6.1143)=173.22, \mathrm{p}<.000\right)$ and powerfulness of firm in competition against rivals is predicted by commitment and positive relation$\operatorname{ship}\left(\mathrm{R}^{2}=.302, \mathrm{~F}(6.1143)=82.447, \mathrm{p}<.000\right)$. 
Table 1. Connections between the innovation climate and individual and organisational level factors in China (according to standardised regression coefficient Beta)

\begin{tabular}{|c|c|c|c|c|c|}
\hline & Innovation climate factors & $\mathbf{B}$ & Beta & $\mathbf{T}$ & Sig. \\
\hline \multirow{6}{*}{$\begin{array}{l}\text { Job satisfaction } \\
\mathrm{n}=1150, \mathrm{R}^{2}=.199 \\
\mathrm{~F}(6.1143)=47.454 \\
\mathrm{p}<.000\end{array}$} & Commitment & .115 & .205 & 5.707 & $.000 *$ \\
\hline & Positive relationship & .904 & .099 & 1.825 & .068 \\
\hline & Shared view & .777 & .270 & 3.122 & $.001 *$ \\
\hline & Freedom & .497 & .258 & 3.983 & $.000 *$ \\
\hline & Idea-support & -.858 & -.044 & -0.870 & .384 \\
\hline & Risk-taking & -.505 & -.321 & -3.563 & $.000 *$ \\
\hline \multirow{6}{*}{$\begin{array}{l}\text { Meaning of work } \\
n=1150, R^{2}=.161 \\
F(6.1143)=36.739 \\
p<.000\end{array}$} & Commitment & .396 & .129 & 3.534 & $.000 *$ \\
\hline & Positive relationship & .703 & .033 & 0.602 & .546 \\
\hline & Shared view & -.431 & .007 & -0.087 & .930 \\
\hline & Freedom & .028 & .067 & 1.010 & .312 \\
\hline & Idea-support & .315 & .254 & 4.898 & $.000 *$ \\
\hline & Risk-taking & -.805 & .020 & -0.217 & .827 \\
\hline \multirow{6}{*}{$\begin{array}{l}\begin{array}{l}\text { Attitude toward } \\
\text { the firm } \\
\mathrm{n}=1150, \mathrm{R}^{2}=.316 \\
\mathrm{~F}(6.1143)=89.729 \\
\mathrm{p}<.000\end{array}\end{array}$} & Commitment & .587 & .147 & 4.446 & $.000 *$ \\
\hline & Positive relationship & .385 & .169 & 3.368 & $.000 *$ \\
\hline & Shared view & .505 & .189 & 2.378 & .017 \\
\hline & Freedom & .592 & .250 & 4.188 & $.000 *$ \\
\hline & Idea-support & .166 & .023 & 0.507 & .612 \\
\hline & Risk-taking & -.367 & -.150 & -1.810 & .070 \\
\hline \multirow{6}{*}{$\begin{array}{l}\text { Powerfulness of firm } \\
\text { in competition } \\
\text { against rivals } \\
n=1150, R^{2}=.302 \\
F(6.1143)=82.447 \\
p<.000\end{array}$} & Commitment & .177 & .135 & 4.032 & $.000 *$ \\
\hline & Positive relationship & .496 & .151 & 2.958 & $.003 *$ \\
\hline & Shared view & -.514 & -.054 & -0.679 & .496 \\
\hline & Freedom & .840 & .128 & 2.130 & .033 \\
\hline & Idea-support & .307 & .095 & 2.024 & .043 \\
\hline & Risk-taking & .225 & .167 & 1.990 & .046 \\
\hline \multirow{6}{*}{$\begin{array}{l}\text { Behaviour of } \\
\text { management } \\
n=1150, R^{2}=.473 \\
F(6.1143)=173.22 \\
p<.000\end{array}$} & Commitment & .114 & .208 & 7.196 & $.000 *$ \\
\hline & Positive relationship & .403 & .075 & 1.696 & .090 \\
\hline & Shared view & -.023 & -.116 & -1.667 & .095 \\
\hline & Freedom & .167 & .286 & 5.470 & $.000 *$ \\
\hline & Idea-support & .061 & .123 & 3.018 & $.002 *$ \\
\hline & Risk-taking & .343 & .203 & 2.787 & $.005 *$ \\
\hline
\end{tabular}

Note: ${ }^{*}$ - coefficient statistically significant, $\mathrm{p}<0,01$.

According to the linear regression analysis results in Table 2, in Japanese enterprises individual level factors - job satisfaction is predicted by innovation climate factors commitment, shared view, freedom and idea-support $\left(\mathrm{R}^{2}=.053, \mathrm{~F}(6.1563)=15.922\right.$, $\mathrm{p}<.000)$, meaning of work is predicted by commitment, positive relationship and risk-taking $\left(\mathrm{R}^{2}=.161, \mathrm{~F}(6.1563)=51.402, \mathrm{p}<.000\right)$ and attitude toward the work is 
predicted by commitment, shared view and freedom $\left(\mathrm{R}^{2}=.767, \mathrm{~F}(6.1563)=866.10\right.$, $\mathrm{p}<.000$ ). Organisational level factors - behaviour of management is predicted by commitment, positive relationship, freedom and risk-taking $\left(\mathrm{R}^{2}=.632, \mathrm{~F}(6.1143)=173.22\right.$, $\mathrm{p}<.000)$ and powerfulness of firm in competition against rivals is predicted by commitment, positive relationship, freedom and risk-taking $\left(\mathrm{R}^{2}=.444, \mathrm{~F}(6.1563)=208.65\right.$, $\mathrm{p}<.000)$.

Table 2. Connections between the innovation climate and individual and organisational level factors in Japan (according to standardised regression coefficient Beta)

\begin{tabular}{|c|c|c|c|c|c|}
\hline & Innovation climate factors & $\mathbf{B}$ & Beta & $\mathbf{T}$ & Sig. \\
\hline \multirow{6}{*}{$\begin{array}{l}\text { Job satisfaction } \\
\mathrm{n}=1570, \mathrm{R}^{2}=.053 \\
\mathrm{~F}(6.1563)=15.922 \\
\mathrm{p}<.000\end{array}$} & Commitment & .592 & .319 & 7.471 & $.000^{*}$ \\
\hline & Positive relationship & .369 & .121 & 1.951 & .051 \\
\hline & Shared view & .191 & .247 & 3.250 & $.001 *$ \\
\hline & Freedom & -.169 & -.440 & -6.139 & $.000 *$ \\
\hline & Idea-support & -.801 & -.182 & -3.409 & $.000^{*}$ \\
\hline & Risk-taking & .680 & .125 & 1.740 & .082 \\
\hline \multirow{6}{*}{$\begin{array}{l}\text { Meaning of work } \\
\mathrm{n}=1570, \mathrm{R}^{2}=.161 \\
\mathrm{~F}(6.1563)=51.402 \\
\mathrm{p}<.000\end{array}$} & Commitment & .919 & .166 & 4.125 & $.000 *$ \\
\hline & Positive relationship & .182 & .721 & 12.308 & $.000 *$ \\
\hline & Shared view & .598 & .021 & 0.299 & .764 \\
\hline & Freedom & -.139 & -.097 & -1.446 & .148 \\
\hline & Idea-support & -.128 & -.049 & -0.974 & .330 \\
\hline & Risk-taking & -.428 & -.422 & -6.242 & $.000 *$ \\
\hline \multirow{6}{*}{$\begin{array}{l}\begin{array}{l}\text { Attitude toward } \\
\text { the firm } \\
\mathrm{n}=1570, \mathrm{R}^{2}=.767 \\
\mathrm{~F}(6.1563)=866.10 \\
\mathrm{p}<.000\end{array}\end{array}$} & Commitment & .783 & .384 & 18.147 & $.000 *$ \\
\hline & Positive relationship & -.064 & -.045 & -1.458 & .144 \\
\hline & Shared view & -.212 & -.254 & -6.725 & $.000 *$ \\
\hline & Freedom & .668 & .829 & 23.316 & $.000^{*}$ \\
\hline & Idea-support & -.366 & -.036 & -1.375 & .169 \\
\hline & Risk-taking & -.125 & -.038 & -1.083 & .278 \\
\hline \multirow{6}{*}{$\begin{array}{l}\text { Powerfulness of firm } \\
\text { in competition } \\
\text { against rivals } \\
\mathrm{n}=1570, \mathrm{R}^{2}=.444 \\
\mathrm{~F}(6.1563)=208.65 \\
\mathrm{p}<.000\end{array}$} & Commitment & .303 & .424 & 12.911 & $.000^{*}$ \\
\hline & Positive relationship & .252 & .302 & 6.325 & $.000 *$ \\
\hline & Shared view & -.630 & -.073 & -1.250 & .211 \\
\hline & Freedom & .125 & .377 & 6.843 & $.000 *$ \\
\hline & Idea-support & 619 & .021 & 0.536 & .591 \\
\hline & Risk-taking & -.991 & -.413 & -7.499 & $.000 *$ \\
\hline \multirow{6}{*}{$\begin{array}{l}\text { Behaviour of } \\
\text { management } \\
n=1570, R^{2}=.632 \\
F(6.1563)=447.90 \\
p<.000\end{array}$} & Commitment & .510 & .562 & 21.055 & $.000 *$ \\
\hline & Positive relationship & .638 & .154 & 3.971 & $.000 *$ \\
\hline & Shared view & .709 & .013 & 0.278 & .780 \\
\hline & Freedom & .151 & .359 & 8.017 & $.000 *$ \\
\hline & Idea-support & .330 & .027 & 0.835 & .403 \\
\hline & Risk-taking & -.808 & -.329 & -7.342 & $.000 *$ \\
\hline
\end{tabular}

Note: $*$ - coefficient statistically significant, $\mathrm{p}<0,01$. 
According to the linear regression analysis results in Table 3, in Estonian enterprises individual level factors - job satisfaction is predicted by innovation climate factor shared view $\left(\mathrm{R}^{2}=.594, \mathrm{~F}(6.607)=150.72, \mathrm{p}<.000\right)$, meaning of work is predicted by commitment, shared view, idea-support and risk-taking $\left(\mathrm{R}^{2}=.464, \mathrm{~F}(6.612)=88.550\right.$, $\mathrm{p}<.000)$ and attitude toward the work is predicted by commitment, shared view and freedom $\left(\mathrm{R}^{2}=.541, \mathrm{~F}(6.613)=120.65, \mathrm{p}<.000\right)$. Organisational level factors - behaviour of management is predicted by commitment, positive relationship and shared view $\left(\mathrm{R}^{2}=.680, \mathrm{~F}(6.613)=217.21, \mathrm{p}<.000\right)$ and powerfulness of firm in competition against rivals is predicted by shared view $(\mathrm{R} 2=.480, \mathrm{~F}(6.613)=94.497, \mathrm{p}<.000)$.

Table 3. Connections between the innovation climate and individual and organisational level factors in Estonia (according to standardised regression coefficient Beta)

\begin{tabular}{|c|c|c|c|c|c|}
\hline & Innovation climate factors & B & Beta & $\mathbf{T}$ & Sig. \\
\hline \multirow{6}{*}{$\begin{array}{l}\text { Job satisfaction } \\
\mathrm{n}=623, \mathrm{R}^{2}=.594 \\
\mathrm{~F}(6.607)=150.72 \\
\mathrm{P}<.000\end{array}$} & Commitment & -.559 & -.060 & -2.120 & .034 \\
\hline & Positive relationship & .359 & .053 & 1.462 & .144 \\
\hline & Shared view & .272 & .712 & 17.928 & $.000 *$ \\
\hline & Freedom & -.274 & -.040 & -1.105 & .269 \\
\hline & Idea-support & -.758 & -.072 & -2.270 & .023 \\
\hline & Risk-taking & -.291 & -.027 & -0.727 & .467 \\
\hline \multirow{6}{*}{$\begin{array}{l}\text { Meaning of work } \\
\mathrm{n}=623, \mathrm{R}^{2}=.464 \\
\mathrm{~F}(6.612)=88.550 \\
\mathrm{p}<.000\end{array}$} & Commitment & -.288 & -.087 & -2.669 & $.000 *$ \\
\hline & Positive relationship & .146 & .061 & 1.448 & .148 \\
\hline & Shared view & .395 & .348 & 7.570 & $.000 *$ \\
\hline & Freedom & .175 & .074 & 1.724 & .085 \\
\hline & Idea-support & -.497 & -.133 & -3.620 & $.000 *$ \\
\hline & Risk-taking & .648 & .170 & 3.929 & $.000 *$ \\
\hline \multirow{6}{*}{$\begin{array}{l}\begin{array}{l}\text { Attitude toward } \\
\text { the firm } \\
\mathrm{n}=623, \mathrm{R}^{2}=.541 \\
\mathrm{~F}(6.613)=120.65 \\
\mathrm{p}<.000\end{array}\end{array}$} & Commitment & .357 & .115 & 3.789 & $.000 *$ \\
\hline & Positive relationship & .196 & .087 & 2.234 & .025 \\
\hline & Shared view & .547 & .511 & 12.036 & $.000 *$ \\
\hline & Freedom & .429 & .192 & 4.849 & $.000 *$ \\
\hline & Idea-support & .052 & .014 & 0.435 & .663 \\
\hline & Risk-taking & .337 & .094 & 2.347 & .019 \\
\hline \multirow{6}{*}{$\begin{array}{l}\text { Powerfulness of firm } \\
\text { in competition } \\
\text { against rivals } \\
n=623, \mathrm{R}^{2}=.480 \\
\mathrm{~F}(6.613)=94.497 \\
\mathrm{P}<.000\end{array}$} & Commitment & -.165 & -.035 & -1.101 & .271 \\
\hline & Positive relationship & .249 & .074 & 1.775 & .076 \\
\hline & Shared view & .004 & .625 & 13.833 & $.000 *$ \\
\hline & Freedom & .115 & .034 & 0.817 & .414 \\
\hline & Idea-support & .140 & .026 & 0.737 & .460 \\
\hline & Risk-taking & -.039 & -.007 & -0.173 & .862 \\
\hline \multirow{6}{*}{$\begin{array}{l}\begin{array}{l}\text { Behaviour of } \\
\text { management } \\
n=623, R^{2}=.680, \\
F(6.613)=217.21, \\
\mathrm{P}<.000\end{array}\end{array}$} & Commitment & -.277 & -.069 & -2.736 & $.006 *$ \\
\hline & Positive relationship & .255 & .088 & 2.694 & $.007 *$ \\
\hline & Shared view & .989 & .716 & 20.202 & $.000 *$ \\
\hline & Freedom & .054 & .019 & 0.576 & .564 \\
\hline & Idea-support & .023 & .005 & 0.180 & .857 \\
\hline & Risk-taking & .086 & .018 & 0.560 & .575 \\
\hline
\end{tabular}

Note: ${ }^{*}$ - coefficient statistically significant, $\mathrm{p}<0,01$. 
According to the linear regression analysis results in Table 4, in Czech enterprises individual level factors - job satisfaction is predicted by innovation climate factor - commitment $\left(\mathrm{R}^{2}=.128, \mathrm{~F}(6.1103)=27.140, \mathrm{p}<.000\right)$, meaning of work is predicted by commitment and idea-support $(\mathrm{R} 2=.134, \mathrm{~F}(6.1103)=28.511, \mathrm{p}<.000)$ and attitude toward the work is predicted by commitment, freedom, idea-support and risk-taking $\left(\mathrm{R}^{2}=.488, \mathrm{~F}(6.1103)=175.29, \mathrm{p}<.000\right)$. Organisational level factors - behaviour of management is predicted by commitment, shared view and freedom $\left(\mathrm{R}^{2}=.680\right.$, $\mathrm{F}(6.613)=217.21, \mathrm{p}<.000)$ and powerfulness of firm in competition against rivals is predicted by shared view and idea-support $\left(\mathrm{R}^{2}=.164, \mathrm{~F}(6.1103)=36.301, \mathrm{p}<.000\right)$.

Table 4. Connections between the innovation climate and individual and organisational level factors in Czech Republic (according to standardised regression coefficient Beta)

\begin{tabular}{|c|c|c|c|c|c|}
\hline & Innovation climate factors & $\mathbf{B}$ & Beta & $\mathbf{T}$ & Sig. \\
\hline \multirow{6}{*}{$\begin{array}{l}\text { Job satisfaction } \\
\mathrm{n}=1110, \mathrm{R}^{2}=.128 \\
\mathrm{~F}(6.1103)=27.140 \\
\mathrm{P}<.000\end{array}$} & Commitment & .146 & .182 & 5.175 & $.000 *$ \\
\hline & Positive relationship & .419 & .088 & 1.933 & .053 \\
\hline & Shared view & .910 & .075 & 1.403 & .160 \\
\hline & Freedom & .547 & .119 & 2.205 & .027 \\
\hline & Idea-support & .265 & .031 & 0.607 & .543 \\
\hline & Risk-taking & -.303 & -.074 & -1.470 & .141 \\
\hline \multirow{6}{*}{$\begin{array}{l}\text { Meaning of work } \\
\mathrm{n}=1110, \mathrm{R}^{2}=.134 \\
\mathrm{~F}(6.1103)=28.511 \\
\mathrm{p}<.000\end{array}$} & Commitment & .649 & .150 & 4.277 & $.000 *$ \\
\hline & Positive relationship & .822 & .066 & 1.443 & .149 \\
\hline & Shared view & -.065 & -.005 & -0.108 & .913 \\
\hline & Freedom & .061 & .024 & 0.451 & .651 \\
\hline & Idea-support & .875 & .255 & 4.908 & $.000 *$ \\
\hline & Risk-taking & -.532 & -.048 & -0.962 & .335 \\
\hline \multirow{6}{*}{$\begin{array}{l}\begin{array}{l}\text { Attitude toward } \\
\text { the firm } \\
\mathrm{n}=1110, \mathrm{R}^{2}=.488 \\
\mathrm{~F}(6.1103)=175.29 \\
\mathrm{p}<.000\end{array}\end{array}$} & Commitment & .637 & .289 & 10.683 & $.000 *$ \\
\hline & Positive relationship & -.000 & -.047 & -1.343 & .179 \\
\hline & Shared view & .218 & .062 & 1.503 & .132 \\
\hline & Freedom & .426 & .484 & 11.621 & $.000 *$ \\
\hline & Idea-support & .119 & .107 & 2.676 & $.007 *$ \\
\hline & Risk-taking & -.541 & -.124 & -3.179 & $.001 \%$ \\
\hline \multirow{6}{*}{$\begin{array}{l}\text { Powerfulness of firm } \\
\text { in competition } \\
\text { against rivals } \\
n=1110, R^{2}=.164, \\
F(6.1103)=36.301, \\
p<.000\end{array}$} & Commitment & .219 & .074 & 5.629 & .030 \\
\hline & Positive relationship & .119 & .013 & 1.697 & .763 \\
\hline & Shared view & .464 & .184 & 1.847 & $.000 *$ \\
\hline & Freedom & .242 & .099 & 2.799 & .061 \\
\hline & Idea-support & .237 & .173 & 9.535 & $.000 *$ \\
\hline & Risk-taking & -.808 & -.085 & 3.973 & .086 \\
\hline \multirow{6}{*}{ 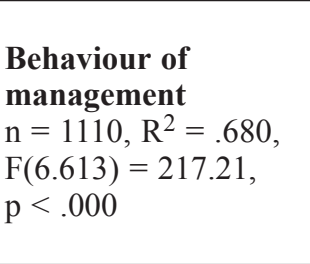 } & Commitment & .665 & .231 & 8.061 & $.000 *$ \\
\hline & Positive relationship & .208 & .072 & 1.938 & .052 \\
\hline & Shared view & .098 & .135 & 3.095 & $.002 *$ \\
\hline & Freedom & .796 & .249 & 5.642 & $.000 *$ \\
\hline & Idea-support & .099 & .086 & 2.028 & .042 \\
\hline & Risk-taking & .548 & .002 & 0.065 & .947 \\
\hline
\end{tabular}

Note: $*$ - coefficient statistically significant, $\mathrm{p}<0,01$. 
According to the linear regression analysis results in Table 5, in Slovakian enterprises individual level factors - job satisfaction is predicted by innovation climate factors commitment, shared view and idea-support $\left(\mathrm{R}^{2}=.248, \mathrm{~F}(6.598)=32.893, \mathrm{p}<.000\right)$, meaning of work is predicted by idea-support $\left(\mathrm{R}^{2}=.085, \mathrm{~F}(6.598)=9.369, \mathrm{p}<.000\right)$ and attitude toward the work is predicted by commitment and freedom $\left(\mathrm{R}^{2}=.663\right.$, $\mathrm{F}(6.598)=196.46, \mathrm{p}<.000)$. Organisational level factors - behaviour of management is predicted by commitment and freedom $\left(\mathrm{R}^{2}=.650, \mathrm{~F}(6.598)=185.44, \mathrm{p}<.000\right)$ and powerfulness of firm in competition against rivals is predicted by commitment and freedom $\left(\mathrm{R}^{2}=.241, \mathrm{~F}(6.598)=31.737, \mathrm{p}<.000\right)$.

Table 5. Connections between the innovation climate and individual and organisational level factors in Slovakia (according to standardised regression coefficient Beta)

\begin{tabular}{|c|c|c|c|c|c|}
\hline & Innovation climate factors & B & Beta & $\mathbf{T}$ & Sig. \\
\hline \multirow{6}{*}{$\begin{array}{l}\text { Job satisfaction } \\
n=605, R^{2}=.248 \\
F(6.598)=32.893 \\
p<.000\end{array}$} & Commitment & .382 & .216 & 3.478 & $.000 *$ \\
\hline & Positive relationship & -.016 & -.034 & -0.344 & .730 \\
\hline & Shared view & .021 & .367 & 3.547 & $.000 *$ \\
\hline & Freedom & .803 & .162 & 1.848 & .064 \\
\hline & Idea-support & -.108 & -.418 & -4.157 & $.000 *$ \\
\hline & Risk-taking & .435 & .188 & 2.095 & .036 \\
\hline \multirow{6}{*}{$\begin{array}{l}\text { Meaning of work } \\
\mathrm{n}=605, \mathrm{R}^{2}=.085 \\
\mathrm{~F}(6.598)=9.369 \\
\mathrm{p}<.000\end{array}$} & Commitment & .643 & .093 & 1.365 & .172 \\
\hline & Positive relationship & .831 & .210 & 1.916 & .055 \\
\hline & Shared view & .814 & .143 & 1.259 & .208 \\
\hline & Freedom & .388 & .073 & 0.754 & .451 \\
\hline & Idea-support & -.215 & -.416 & -3.758 & $.000 *$ \\
\hline & Risk-taking & .432 & .156 & 1.584 & .113 \\
\hline \multirow{6}{*}{$\begin{array}{l}\text { Attitude toward } \\
\text { the firm } \\
\mathrm{n}=605, \mathrm{R}^{2}=.663, \\
\mathrm{~F}(6.598)=196.46 \\
\mathrm{p}<.000\end{array}$} & Commitment & .110 & .376 & 9.051 & $.000 *$ \\
\hline & Positive relationship & .968 & .191 & 2.878 & .004 \\
\hline & Shared view & -.364 & -.007 & -0.101 & .919 \\
\hline & Freedom & .275 & .436 & 7.421 & $.000 *$ \\
\hline & Idea-support & -.529 & -.046 & -0.692 & .488 \\
\hline & Risk-taking & -.124 & -.096 & -1.601 & .109 \\
\hline \multirow{6}{*}{$\begin{array}{l}\text { Powerfulness of firm } \\
\text { in competition } \\
\text { against rivals } \\
\mathrm{n}=605, \mathrm{R}^{2}=.241 \\
\mathrm{~F}(6.598)=31.737 \\
\mathrm{P}<.000\end{array}$} & Commitment & .401 & .262 & 4.204 & $.000 *$ \\
\hline & Positive relationship & .128 & .132 & 1.325 & .185 \\
\hline & Shared view & .351 & .054 & 0.521 & .602 \\
\hline & Freedom & .602 & .245 & 2.782 & $.005 *$ \\
\hline & Idea-support & -.660 & -.138 & -1.367 & .172 \\
\hline & Risk-taking & -.229 & -.052 & -0.580 & .561 \\
\hline \multirow{6}{*}{$\begin{array}{l}\text { Behaviour of } \\
\text { management } \\
\mathrm{n}=605, \mathrm{R}^{2}=.650 \\
\mathrm{~F}(6.598)=185.44 \\
\mathrm{P}<.000\end{array}$} & Commitment & .430 & .525 & 12.381 & $.000 *$ \\
\hline & Positive relationship & .453 & .153 & 2.258 & .024 \\
\hline & Shared view & .631 & .108 & 1.539 & .124 \\
\hline & Freedom & .056 & .223 & 3.733 & $.000 *$ \\
\hline & Idea-support & -.386 & -.151 & -2.202 & .027 \\
\hline & Risk-taking & -.862 & -.016 & -0.272 & .785 \\
\hline
\end{tabular}

Note: * coefficient statistically significant, $\mathrm{p}<0,01$. 
Summary of the results is following. In these organisations where climate for innovation is highly valued employees are more satisfied with their work, they think that their work has a meaning and they have more positive attitudes toward their organisation. Innovative organisations are more powerful in competition against rivals. Managers also value innovation in these organisations and support it.

Current study results show that innovation climate factor - commitment - predicts job satisfaction in Chinese, Japanese, Czech and Slovakian organisations. Employees are more satisfied with their job in the organisations when they care for the organisation they are working for and where most capable people commit to decisions to solve an urgent problem.

Innovation climate factor - shared view - predicts job satisfaction in Chinese, Japanese, Estonian and Slovakian organisations. Employees, who attend seminars organized by the organisation, who clearly imagine the future of their organisation and who are aware of the important role of their organisation in society, are more satisfied with their job.

Innovation climate factor - commitment - predicts meaning of work in Chinese, Japanese, Estonian and Czech organisations. Employees find their job more meaningful in the organisations when they care for the organisation they are working for and where most capable persons commit to decisions to solve an urgent problem. Innovation climate factor - idea-support predicts meaning of work in Chinese, Estonian, Czech and Slovakian organisations. In organisations where fresh creative ideas are recognized in time people evaluate their job as more meaningful.

There are fewer differences between countries concerning innovative climate facets that predict organisation level factors. Innovation climate factor - commitment - predicts attitude toward the firm in Chinese, Japanese, Estonian, Czech and Slovakian organisations. Employees have more positive attitude toward the organisation when they care for the organisation they are working for and where most capable people commit to decisions to solve an urgent problem.

Innovation climate factor - freedom - predicts attitude toward the firm in Chinese, Japanese, Estonian, Czech and Slovakian organisations. Employees have more positive attitude toward the organisation that relies more on coordination, rather than strict hierarchy and where department's leader may hire temporary workers by themselves.

Innovation climate factor - commitment - predicts behaviour of management in Chinese, Japanese, Estonian, Czech and Slovakian organisations. Behaviour of management is positively influenced by employees who care for the organisation they are working for and where most capable persons commit to decisions to solve an urgent problem.

\section{Discussions and conclusions}

It can be concluded that the innovation climate predicts individual and organisational level factors but impact varies between countries. Than can be explained by referring to cultural and institutional differences that influence business environment and organisations. 
The main findings of the current study are following. The innovation climate factors predict partly individual level factors in Chinese, Japanese, Estonian, Czech and Slovakian organisations. In two studied Asian countries, Japan and China, commitment predicts meaning of work and job satisfaction whereas in all three new European Union member states some links between facets of the innovation climate and individual meaning of work and job satisfaction were missing. It seems that motivating employees and assisting them in personal work-related sense-making in these European countries is for innovative leaders a more complicated challenge than in Asia.

Higher impact of shared views and commitment on job satisfaction can be explained by higher degree of collectivism in many Asian countries that was studied by Hofstede (1980) already several decades ago but has been supported by new evidence and interpretations in Hofstede et al. (2010). The research result that in Japan idea-support does not predict meaning of work may be evidence of high support to ideas of employees in all studied organisations of this country. At the same time innovation climate predicts organisation level factors in more universal way both in Asia and Europe.

It can be concluded that although individual job satisfaction and meaning of work in is still shaped by to some extent different mechanisms in studies countries, implications of the innovative climate for organisation are more similar, at least in industries that are influenced by rapid technological development and globalization.

Despite of the very different institutional background there are specific features of innovation climate that has impact on concrete individual and organisational level factors (e.g. innovation climate factor - commitment - predicts job satisfaction in Chinese, Japanese, Czech and Slovakian organisations, innovation climate factor - shared view predicts job satisfaction in Chinese, Japanese, Estonian and Slovakian organisations). Therefore, for example, concerning job satisfaction it is more important to have shared view with you colleagues and socialist planned, capitalistic or transformational economies have less influence on employees job satisfaction.

As the environmental changes and demands organisations and managers to change and adapt to new conditions, innovations are the vehicle to introduce change into outputs, structure and processes and factors at different levels - individual, organisational and environmental (Fariborz 1991). According to Alas and Edwards (2005), the differences in attitudes held toward society, organisations and work by people in Asia and Europe are influenced both by institutional context and cultural background. Alas, Kraus and Niglas (2009) state that obtaining knowledge about traditions and customs in concrete country is useful before starting production in this country.

Implications for managers and policy makers from this study are following. Innovation climate is a complex entity. The innovation climate facets predict all organisational level factors - powerfulness of firm in competition against rivals and behaviour of management. The innovation climate predicts almost all individual level factors - job satisfaction, meaning of work and attitude toward the firm in this study, except the innovation climate facet - positive relationship does not predict job satisfaction and 
the innovation climate facet - freedom does not predict meaning of work. In different countries innovation climate facets predict individual and organisational level factors differently. Therefore, leaders and policy makers have to take into account findings of current research while creating an innovative climate in an organisation.

There are limitations in this study related to its general framework. The authors have focused only on certain factors - individual and organisational level factors that are influenced by the innovation climate, but there could be other factors also. The authors explored connections between a limited number of factors and the other influences have been left for future research. Corporate social responsibility and ethical values in business could be studied and analyzed concerning the innovation climate.

This research was conducted among Estonian, Chinese, Japanese, Slovakian and Czech electric-electronic machine, retail store, information-software production and machinebuilding enterprises. Researches in other countries and in other branches should be done in order to overcome sector-specific limitations of this research. The concept of the innovation climate should be studied in more detail in further studies by using the results gained in this research.

\section{References}

Aarons, G. A.; Sawitzky, A. C. 2006. Organisational culture and climate and mental health provider attitudes toward evidence-based practice, Psychological Services 3(1): 61-72.

http://dx.doi.org/10.1037/1541-1559.3.1.61

Alas, R. 2003. Consequences of socialism in employee's attitudes, Journal of Business Economics and Management 4(1): 45-52.

Alas, R.; Edwards, V. 2005. Work-related attitudes: a comparison of Estonia and Finland, Journal of Business Economics and Management 6(4): 207-217.

Alas, R.; Tuulik, K. 2007. Cultural practices and values at the societal level in Estonia in comparison with neighbouring countries, Journal of Business Economics and Management 8(1): 39-44.

Alas, R. 2008. Implementation of organizational changes in Estonian companies, Journal of Business Economics and Management 9(4): 289-297.

http://dx.doi.org/10.3846/1611-1699.2008.9.289-297

Alas, R.; Kraus, A.; Niglas, K. 2009. Manufacturing strategies and choices in cultural contexts, Journal of Business Economics and Management 10(4): 279-289.

http://dx.doi.org/10.3846/1611-1699.2009.10.279-289

Alas, R.; Edwards, V. 2011. Work-related attitudes in Asia and Europe: institutional approach, Engineering Economics 22(1): 24-31.

Amabile, T. M.; Conti, R.; Coon, H.; Lazenby, J.; Herron, M. 1996. Assessing the working environment for creativity, Academy of Management Journal 39: 1154-1184.

http://dx.doi.org/10.2307/256995

Anderson, N. R.; de Dreu, C. K. W.; Nijstad, B. A. 2004. The routinization of innovation research: a constructively critical review of the state-of-the-science, Journal of Organisational Behaviour 25(2): 147-174. http://dx.doi.org/10.1002/job.236

Ansoff, H. I. 1988. The New Corporate Strategy. New York: Wiley.

Ashforth, B. E. 1985. Climate formation: issues and extensions, Academy of Management Review 10(4): 837-847. 
Ashkanasy, N. M.; Wijderom, C. P. M.; Peterson, M. F. 2000. Handbook of Organisational Culture and Climate. Thousand Oaks, CA: Sage.

Barney, J. 1986. Organisational culture, Academy of Management Review 11(3): 656-665. http://dx.doi.org/10.5465/AMR.1986.4306261

Betz, F. 1987. Managing Technology: Competing Through New Ventures, Innovation, and Corporate Research. Englewood Cliffs, NJ: Prentice Hall.

Birkinshaw, J.; Mol, M. 2006. How management innovation happens, Management of Technology and Innovation 47(4): 81-88.

Brayfield, A. H.; Rothe, H. F. 1951. An index of job satisfaction, Journal of Applied Psychology 35: 307-311. http://dx.doi.org/10.1037/h0055617

Brown, C. J.; Frame, P. 2004. Subjectivity in innovation management, International Journal of Innovation and Learning 1(4): 351-363. http://dx.doi.org/10.1504/IJIL.2004.005496

Buckler, S. A.; Zien, K. A. 1996. From experience: the spirituality of innovation: leaming from stories, The Journal of Product Innovation Management 13(5): 391-405.

http://dx.doi.org/10.1016/0737-6782(96)00056-2

Cameron, K. S.; Freeman, S. J. 1991. Cultural congruence, strength and type: relationships to effectiveness, Research in Organisational Change and Development 5: 23-58.

Cameron, K. S.; Quinn, R. E. 1999. Diagnosing and Changing Organisational Culture: Based on the Competing Values Framework. Addison Wesley: Longman.

Carmazzi, A.; Aarons, G. A. 2003. Organisational culture and attitudes toward adoption of evidence-based practice, paper presented at the NASMHPD Research Institute's 2003 Conference on State Mental Health Agency Services Research, Program Evaluation, and Policy, Baltimore, MD. 299.

Clark, K. 1987. Investment in new technology and competitive advantage, in D. J. Teece (Ed.). The Competitive Challenge. Grand Rapids, MI: Harper and Row, 59-82.

Damanpour, F.; Schneider, M. 2006. Phases of the adoption of innovation in organisations: effects of environment, organisation and top managers, British Journal of Management 17: 215-236. http://dx.doi.org/10.1111/j.1467-8551.2006.00498.x

Deming, W. E. 1986. Out of the Crisis. Cambridge, MA: MIT Center for Advanced Engineering Study.

Dewey, J. 1939. Theory of Valuation. Chicago, IL: University of Chicago Press.

Ekvall, G.; Arvonen, I.; Waldenstrom-Lindblads, I. 1983. Creative organisational climate: construction and validation of a measuring instrument, Report 2. Stockholm: FA radet, The Swedish Council for Management and Organisational Behavior.

Ekvall, G. 1990. Work Climate: Manual Form A. Stockholm: G. E. Organizational psychology.

Ekvall, G.; Ryhammar, L. 1999. The creative organisational climate. Its determinants and effects at a Swedish University, Creativity Research Journal 12: 303-310.

http://dx.doi.org/10.1207/s15326934crj1204_8

Ekvall, G. 1999. Creative organizational climate, in M. A. Runco, S. R. Pritzker (Eds.). Encyclopedia of Creativity. San Diego, CA: Academic Press, 403-412.

Fariborz, D. 1991. Organisational innovation: a meta-analysis of effects of determinants and moderators, Academy of Management Journal 34(3): 555-590. http://dx.doi.org/10.2307/256406

Garcia-Gofii, M.; Maroto, A.; Rubalcaba, L. 2007. Innovation and motivation in public health professionals, Health Policy 84(2): 344-358. http://dx.doi.org/10.1016/j.healthpol.2007.05.006

Glisson, C.; Hemmelgarn, A. 1998. The effects of organisational climate and inter organisational coordination on the quality and outcomes of children's service systems, Child Abuse and Neglect 22(5): 401-421. http://dx.doi.org/10.1016/S0145-2134(98)00005-2 
Glisson, C.; Lames, L. R. 2002. The cross-level effects of culture and climate in human service teams, Journal of Organisational Behavior 23: 767-794. http://dx.doi.org/10.1002/job.162

Hackman, R. L.; Oldham, G. R. 1975. Development of the lob diagnostic survey, Journal of Applied Psychology 60(2): 159-170. http://dx.doi.org/10.1037/h0076546

Hackman, R. L; Oldham, G. R. 1976. Motivation through design of work, Organisational Behaviour and Human Performance 16: 250-279. http://dx.doi.org/10.1016/0030-5073(76)90016-7

Herzberg, F. 1968. One more time: how do you motivate employees?, Harvard Business Review 46(1): 53-62.

Hofstede, G. 1980. Culture's Consequences: International Differences in Work-Related Values. Beverly Hills, CA: Sage.

Hofstede, G.; Hofstede, G. J.; Minkov, M. 2010. Cultures and Organizations. New York: McGraw-Hill.

Ishikawa, A.; Mako, C.; Warhurst, C. 2006. Work and Employee Representation: Workers, Firms and Unions. Part 3. Tokyo: Chuo University Press.

Jones, S. 1995. The democratic dimension of quality, innovation and long-term success, The TQM Magazine 7(2): 36-41. http://dx.doi.org/10.1108/09544789510081108

Judge, W. Q.; Fryxell, G. E.; Dooley, R. S. 1997. The new task of R\&D management: creating goal-directed communities for innovation, California Management Review 39(3): 72-85.

Judge, T. A.; Thoresen, C. L.; Bono, J. E.; Patton, G. K. 2001. The job satisfaction-job performance relationship: a qualitative and quantitative review, Psychological Bulletin 127(3): 376407. http://dx.doi.org/10.1037/0033-2909.127.3.376

Kanne-Urrabazo, C. 2006. Management's role in shaping organisational culture, Journal of Nursing Management 14(3): 188-194. http://dx.doi.org/10.1111/j.1365-2934.2006.00590.x

Kanter, R. M. 1983. The Change Masters. New York: Simon and Schuster.

Locke, E. A. 1976. The nature and causes of job satisfaction, in M. D. Dunnette (Ed.). Handbook of Industrial and Organisational Psychology. Chicago, IL: Rand McNally, 1297-1349.

Lund, D. B. 2003. Organisational culture and job satisfaction, The Journal of Business and Industrial Marketing 18(3): 219-236. http://dx.doi.org/10.1108/0885862031047313

Martins, E. C.; Terblanche, F. 2003. Building organisational culture that stimulates creativity and innovation, European Journal of Innovation Management 6(1): 64-74.

http://dx.doi.org/10.1108/14601060310456337

Mathisen, G. E.; Einarsen, S. 2004. A review of instruments: assessing creative and innovative environments within organizations, Creativity Research Journal 16: 119-140.

http://dx.doi.org/10.1207/s15326934crj1601_12

McGregor, D. 1957. An uneasy look at performance appraisal, Harvard Business Review 35(5-6): 89-94.

Meyer, J. P.; Allen, N. J. 1991. A three-component conceptualization of organisational commitment, Human Resource Management Review 1: 61-89.

http://dx.doi.org/10.1016/1053-4822(91)90011-Z

Miller, D. 1990. The Icarus Paradox: How Exceptional Companies Bring About Their Own Downfall. New York: Harper-Collins.

Mumford, M. D.; Gustafson, S. B. 1988. Creativity syndrome: integration, application, and innovation, Psychological Bulletin 103: 27-43. http://dx.doi.org/10.1037/0033-2909.103.1.27

Nyström, H. 1990. Technological and Market Innovation: Strategies for Product and Company Development. Chichester: Wiley. 
Ortt, J. R.; Smits, R. 2006. Innovation management: different approaches to cope with the same trends, International Journal of Technology Management 34: 296-318.

http://dx.doi.org/10.1504/IJTM.2006.009461

Podsakoff, P. M.; Mackenzie, S. B.; Paine, J. B.; Bachrach, D. G. 2000. Organisational citizenship behaviors: a critical review of the theoretical and empirical literature and suggestions for future research, Journal of Management 26: 513-563. http://dx.doi.org/10.1177/014920630002600307

Porter, M. E. 1985. Competitive Advantage. New York: Free Press.

Schein, E. H. 2004. Organisational Culture and Leadership. Chichester: Wiley, John and Sons, Ltd.

Schneider, B.; Reichers, A. E. 1983. On the etiology of climates, Personnel Psychology 36: 19-39. http://dx.doi.org/10.1111/j.1744-6570.1983.tb00500.x

Schneider, B. 1985. Organizational behavior, Annual Review of Psychology 36: 573-611. http://dx.doi.org/10.1146/annurev.ps.36.020185.003041

Seel, R. 2005. Culture and complexity: new insights on organisational change, Organisations and People 7(2): 2-9.

Shipton, H.; West, M. A.; Parkes C.; Dawson J. F. 2004. Aggregate Job Satisfaction, HRM and Organisational Innovation. UK: Aston University, Aston Business School.

Silverthome, C. 2004. The impact of organisational culture and person-organisation fit on organisational commitment and job satisfaction in Taiwan, Leadership and Organisation Development Journal 25(7): 592-599. http://dx.doi.org/10.1108/01437730410561477

Smith, G. P. 2002. The New Leader: Bringing Creativity and Innovation to the Workplace: Chart Your Course. Georgia: Conyers.

Sockel, H.; Mak, B.; Bucholz, J. 2004. The affect of diffusion of technology innovation on burnout, Journal of Management Systems 16(1): 25-37.

Stevens, J. E. 1999. An Organisational Culture Perspective of Strategic Leadership and Organisational Change. Shaping the Future of the Army: Study project.

Tafel, K.; Alas, R. 2007. Various types of Estonian top-managers, Journal of Business Economics and Management 8(3): 189-194.

Teece, D. J.; Pisano, G.; Shuen, A. 1997. Dynamic capabilities and strategic management, Strategic Management Journal 18(7): 509-533.

http://dx.doi.org/10.1002/(SICI)1097-0266(199708)18:7<509::AID-SMJ882>3.0.CO;2-Z

Unsworth, K.; Parker, S. 2003. Proactivity and innovation: promoting a new workforce for the new workplace, in D. Holman, T. Wall, C. Clegg, P. Sparrow, A. Howard (Eds.). The New Workplace: A Guide to the Human Impact of Modern Working Practices. West Sussex, UK: Wiley.

Wright, M.; Filatotchev, I.; Hoskisson, R.; Peng, M. 2005. Strategy research in emerging economies: challenging the conventional wisdom, Journal of Management Studies 42(1): 1-33.

http://dx.doi.org/10.1111/j.1467-6486.2005.00487.x

Zhou, J.; Shalley, C. E. 2003. Research on employee creativity: a critical review and proposal for future research directions, in J. J. Martocchio, G. R. Ferris (Eds.). Research in Personal and Human Resource Management. Oxford: Elsevier. 
Ülle ÜBIUS, Doctor of Philosophy in Management Science. Ülle Übius is scientist in Estonian Business School. Theme of her doctoral thesis was: The Impact of Corporate Social Responsibility, organisational and individual factors on Innovation Climate. She has done researches mainly in the fields of innovation management, innovation climate, corporate social responsibility and organization culture. She is also lecturer. She gives lectures in the following themes: project management, innovation climate, quality management.

Ruth ALAS, Doctor of Philosophy (in Economics). Professor Ruth Alas is the Vice-Rector for Scientific Affairs and Head of Management Department in Estonian Business School. She has written twenty three management textbooks and more than 100 articles. Her research is focusing on employee attitudes, learning abilities, organisational culture, leadership, crises management, business ethics and corporate social responsibility. Ruth Alas has given lectures about change management in Estonia, China and South Africa Republic. Ruth Alas has organized several international conferences in Estonia, and is Chair of EIASM workshops' series 'Organizational development and change'. Ruth Alas is in editorial boards of nine journals.

Tiit ELENURM, Doctor of Philosophy (in Economics). Tiit Elenurm is head of the entrepreneurship department of the Estonian Business School. His vision is to integrate management and entrepreneurship research with training and consultancy activities. Ph.D. in 1980 for the dissertation Management of the Process of Implementation of New Organizational Structures. Research interests include innovative entrepreneurship, knowledge management, corporate governance and international transfer of management knowledge. Author of 127 research publications. 